\title{
CHANGES IN THE LEVEL OF INTERLEUKIN-4 AND INTERLEUKIN-6 IN RESPONSE TO ANGIOPROTECTIVE THERAPY IN CHILDREN WITH SEVERE BIRTH ASPHYXIA
}

Sergey Ovcharenko, Viktoriia Danylova, Violetta Kalnitskaya

Department of Pediatric Surgery and Pediatric Anesthesiology, Kharkiv National Medical University, Kharkiv, Ukraine

\section{PROMENE KONCENTRACIJE INTERLEUKINA-4 I INTERLEUKINA-6 KAO ODGOVORA NA ANGIOPROTEKTIVNU TERAPIJU KOD DECE SA TEŠKOM ASFIKSIJOM NA ROĐENJU}

\author{
Sergej Ovčarenko, Viktorija Danilova, Violeta Kalnicka
}

\section{ABSTRACT}

Objective. The development of clinical and laboratory criteria for diagnosis of systemic inflammatory response significantly expanded the use of this concept in clinical practice. The correlation between the levels of antiinflammatory and pro-inflammatory cytokines is an important aspect in regulation of systemic inflammatory response. Treatment of systemic inflammatory response includes three main links: effect on the levels of endotoxin, cytokines and the state of endothelium. Currently there is no unified approach to the solution of this problem, which determines the relevance of the topic. The aim of the research was to study the efficacy of the deproteinized hemodialysate from the newborn calf blood in systemic inflammatory response in newborns with severe asphyxia at birth.

Methods. The study involved examination of 16 newborns with severe asphyxia at birth, who received a drug as part of standard therapy from the first day of the disease at a dose of $0.5 \mathrm{ml} / \mathrm{kg}$. The study implied a follow-up assessment of interleukin-4 and interleukin-6 levels. Sign test and Wilcoxon test were used for paired samples; Kolmogorov-Smirnov and Mann-Whitney tests were used for non-paired samples. To investigate the influence of the independent variable on the dependent variable we used Kruskal-Wallis and median tests as nonparametric analogs of the variance analysis.

Results. Deproteinized hemodialysate derived from the newborn calf blood is a vasoprotector and is a combination of a number of physiologically active ingredients. They stimulate oxygen utilization by tissues in hypoxic conditions, enhancing glucose transport through biological membranes, intensifying intracellular adenosine triphosphate synthesis, and increasing the proportion of aerobic glycolysis.

Conclusion. Administration of deproteinized hemodialysate from the newborn calf blood in the treatment of systemic inflammatory response in newborns with severe asphyxia at birth exerts influence on biochemical pattern of systemic inflammatory response by reducing inflammation and reducing synthesis of cytokines.

Key words: infant, newborn; asphyxia neonatorum; systemic inflammatory response syndrome; cytokines; blood vessels.

\section{SAŽETAK}

Cilj. Razvoj kliničkih i laboratorijskih kriterijuma za dijagnozu sistemskog inflamatornog odgovora znatno je proširio primenu ovog koncepta u kliničkoj praksi. Korelacija između nivoa antiinflamatornih $i$ proinflamatornih citokina važan je aspekt u regulaciji sistemskog inflamatornog odgovora. Lečenje sistemskog inflamatornog odgovora uključuje tri glavne veze: efekat na koncentracije endotoksina $i$ citokina $i$ stanje endotela. Trenutno ne postoji jedinstveni pristup rešenju ovog problema, koji određuje relevantnost teme. Cilj istraživanja bio je da se prouči efikasnost deproteinizovanog hemodijalizata iz novorođene teleće krvi u sistemskom inflamatornom odgovoru novorođenčadi sa teškom asfiksijom pri rođenju.

Metode. Studija je uključila pregled 16 novorođenčadi sa teškom asfiksijom pri rođenju, koja su primila lek kao deo standardne terapije od prvog dana bolesti u dozi od 0,5 $\mathrm{ml} / \mathrm{kg}$. Studija je podrazumevala naknadnu procenu koncentracije interleukina-4 $i$ interleukina-6. Za uparene uzorke korišceni su test ranga i Vilkokson test; za neuparene uzorke korišceni su testovi Kolmogorov-Smirnov test $i$ Man-Vitni test. Da bismo istražili uticaj nezavisne promenljive na zavisnu promenljivu, koristili smo Kruskal-Vollis test i testiranje medijane kao neparametrijske analoge analize varijanse.

Rezultati. Deproteinizirani hemodijalizat dobijen iz krvi novorodenog teleta je vazoprotektor $i$ predstavlja kombinaciju brojnih fiziološki aktivnih supstanci. One stimulišu korišćenje kiseonika u tkivima u hipoksičnim uslovima, pojačavajuci transport glukoze kroz biološke membrane, intenzivirajuci unutarcélijsku sintezu adenozin trifosfata i povećavajuci učešće aerobne glikolize.

Zaključak. Primena deproteinizovanog hemodijalizata iz krvi novorođene teladi u lečenju sistemskog inflamatornog odgovora novorođenčadi sa teškom asfiksijom pri rođenju utiče na biohemijski obrazac sistemskog inflamatornog odgovora smanjenjem zapaljenja $i$ smanjenjem sinteze citokina.

Ključne reči: odojče, novorođeno; neonatalna asfiksija; sindrom sistemskog inflamatornog odgovora; citokini; krvni sudovi. 


\section{INTRODUCTION}

Metabolic dysregulation in newborns with severe asphyxia at birth is accompanied by discoordination of vital functions of the body, namely disorders of breathing, blood circulation, microcirculation, and others, which suggests participation of systemic inflammatory response in pathogenesis of asphyxia and its consequences. Cytokines have been shown to have diagnostic value in systemic inflammatory response formation in newborns with severe asphyxia at birth (1). Among cytokines there are those promoting (pro-inflammatory), and those interfering with the development of inflammatory process (anti-inflammatory). The relationship between antiinflammatory and pro-inflammatory cytokines is an important aspect in regulation of the onset and development of inflammatory process. This balance affects the course and outcome of the disease. Systemic inflammatory response treatment includes three main links: the impact on endotoxin levels (2-7), cytokines (8$10)$ and the state of endothelium $(2,11)$. Currently there is no unified approach to the solution of this problem, which determines the relevance of the topic.

Of the agents with multifaceted effect on homeostasis, we drew our attention to a vasoprotective agent - the deproteinized hemodialysate from the newborn calf blood (DHNCB), which is a vasoprotector and is a combination of a number of physiologically active ingredients that stimulate tissue oxygen utilization under hypoxic conditions, provide the enhancement of glucose transport through biological membranes, increase intracellular ATP synthesis, and increase the proportion of aerobic glycolysis. Stimulation of oxygen utilization in hypoxia results in normalization of anaerobic metabolism in vascular endothelium, release of prostacyclin and nitric oxide having a vasodilating effect. The above-mentioned mechanisms of action of this agent determine its effectiveness in systemic inflammatory response in newborns who had severe asphyxia at birth.

The aim of the research was to study the efficacy of the deproteinized hemodialysate from the newborn calf blood in systemic inflammatory response in newborns with severe asphyxia at birth.

\section{PATIENTS AND METHODS}

To study the clinical and biochemical picture of the systemic inflammatory response in newborns with severe birth asphyxia and to assess the effectiveness of therapy, we systematized the results of biochemical studies in 16 healthy full-term newborns on the third day of life and in 42 full-term newborns who had severe birth asphyxia, on the third, fifth and seventh days of life. The assessment of the severity of asphyxia was carried out at the first and fifth minutes after birth using the Apgar scale. In all newborns with severe birth asphyxia, at the first minute of life, the Apgar score did not exceed 3 points. They had no spontaneous breathing, bradycardia of less than 100 beats per minute was noted, cyanosis of the skin and mucous membranes, muscle atony and the absence of a reflex of the posterior pharyngeal wall to catheter insertion prevailed. Arrangements for the provision of emergency care consisted in ensuring free airway patency, followed by intubation of the trachea and prosthetics of the external respiratory function with a ventilator, followed by hospitalization in the intensive care unit.

The study involved examination of 16 newborns with severe asphyxia at birth, who received the deproteinized hemodialysate from the newborn calf blood as part of a standard therapy from the first day of the disease at a dose of $0.5 \mathrm{ml} / \mathrm{kg}$ (study group), and to monitor the effectiveness of the therapy we used findings of examination of 26 recovered newborns with similar pathology, receiving standard therapy, corresponding to the protocols for the treatment of severe asphyxia and hypoxic-ischemic lesions of the central nervous system (control group). The study implied a follow-up assessment of interleukin-4 (IL-4), interleukin-6 (IL-6) levels. Biochemical indices in 16 healthy full-term newborns on the third day of life served as a basis for reliability of the results.

The study was carried out in accordance with the Charter of the Ukrainian Association of Bioethics and GCP Norms (1992), in accordance with the requirements and norms of Good Laboratory Practice (2002), Model Provisions on Ethics of the Ministry of Health of Ukraine No. 66 as of 13/02/2006. Informed consent was obtained from the parents for participation of children in the study. The study was approved by the Commission on Ethics and Bioethics of Kharkiv National Medical University (Protocol No. 2 as of 02/03/2012), observing human rights and according to the current legislation in Ukraine; it met international ethical requirements and in accordance with the Declaration of Helsinki and did not violate ethical standards in science and standards for conducting biomedical research. The risk of participating in the study did not differ from the risk in the standard treatment of patients with this abnormality. Prevention of death and disability was considered to be a potential benefit from participation in the study.

Statistical processing of data was performed using general purpose package software Statistica for Windows 6.0. First stage of calculation showed descriptive statistics for the indices measured in a quantitative scale. These characteristics were: median and mean as a measure of position; standard deviation and quartiles as measures of dispersion; lowest and highest value as a measure of the sample range. Distribution of all the analyzed quantitative indices significantly differed from the normal one (Kolmogorov-Smirnov test), therefore, for further 
presentation in the article we mainly use median $\left(50^{\text {th }}\right.$ percentile) and $25^{\text {th }}$ and $75^{\text {th }}$ percentiles (upper and lower quartiles) for their description.

Methods of non-parametric statistics were used to determine the differences between the groups, since if the distribution is far from normal, then the criteria based on estimates of the mean and variance (parametric tests) will give incorrect results. To obtain reliable results, using nonparametric statistical methods, the sample under study must contain at least 16 quantitative indicators, since for statistical processing such characteristics are used as quartiles - dividing the sample into 4 parts, each part must include at least four quantitative indicators. To determine the differences between the groups we used nonparametric statistics methods, since if the distribution is far from normal, the criteria based on mean and variance estimates (parametric criteria) will give incorrect results. Thus, sign test and Wilcoxon test were used for paired samples (time course of treatment); Kolmogorov-Smirnov and MannWhitney tests were used for non-paired samples (subgrouping by feature). To investigate the influence of the independent variable on the dependent variable we used Kruskal-Wallis and median tests as nonparametric analogs of the variance analysis.

Figure 1. Time course of pro-inflammatory cytokine interleukin-4 level in patients in the groups under investigation.

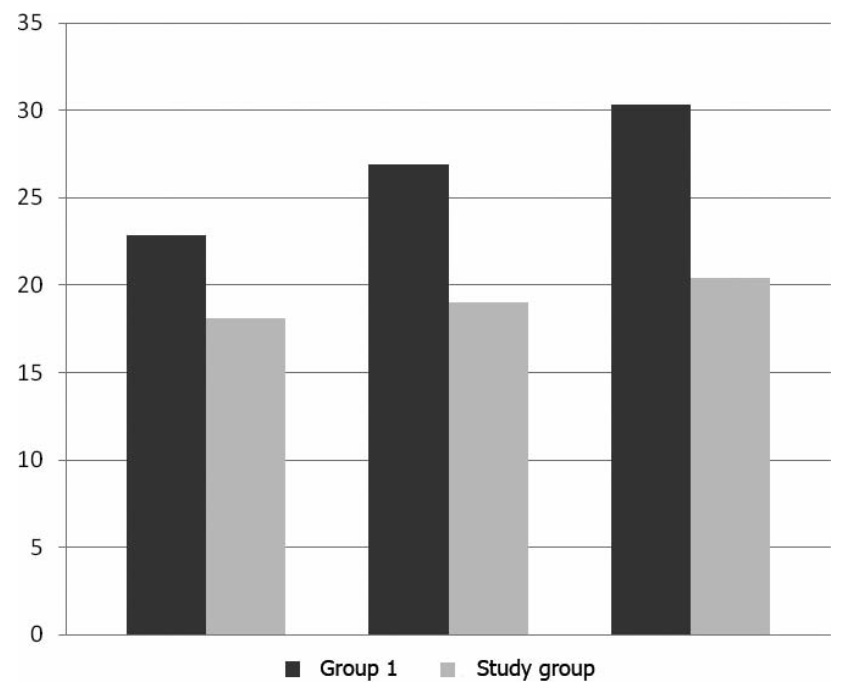

\section{RESULTS}

Table 1 presents interleukin- 4 and interleukin- 6 indices in full-term infants who had severe asphyxia at birth and in healthy full-term newborns on the third day of life. The data presented in Table 1 show that the level of antiinflammatory cytokine interleukin-4 in healthy full-term newborns on the third day of life was $18.73 \mathrm{pg} / \mathrm{ml}$. The level of interleukin-4 in the group of newborns with severe asphyxia at birth receiving standard therapy was 22.89 $\mathrm{pg} / \mathrm{ml}$, which was higher than in healthy newborns and higher than in the newborns of the study group, whose therapy complex included the deproteinized hemodialysate from the newborn calf blood $(18.08 \mathrm{pg} / \mathrm{ml})$.

The level of pro-inflammatory cytokine interleukin-6 in healthy newborns was $104.85 \mathrm{pg} / \mathrm{ml}$, the level of interleukin- 6 in the group of patients receiving standard therapy was $116 \mathrm{pg} / \mathrm{ml}$, whereas in the group of patients whose therapy complex included the deproteinized hemodialysate from the newborn calf blood, the level of interleukin-6 was higher - $170.74 \mathrm{pg} / \mathrm{ml}$.

The time course of indices under investigation in the groups of patients receiving standard therapy, and patients

Figure 2. Time course of pro-inflammatory cytokine interleukin-6 in patients in groups under investigation.

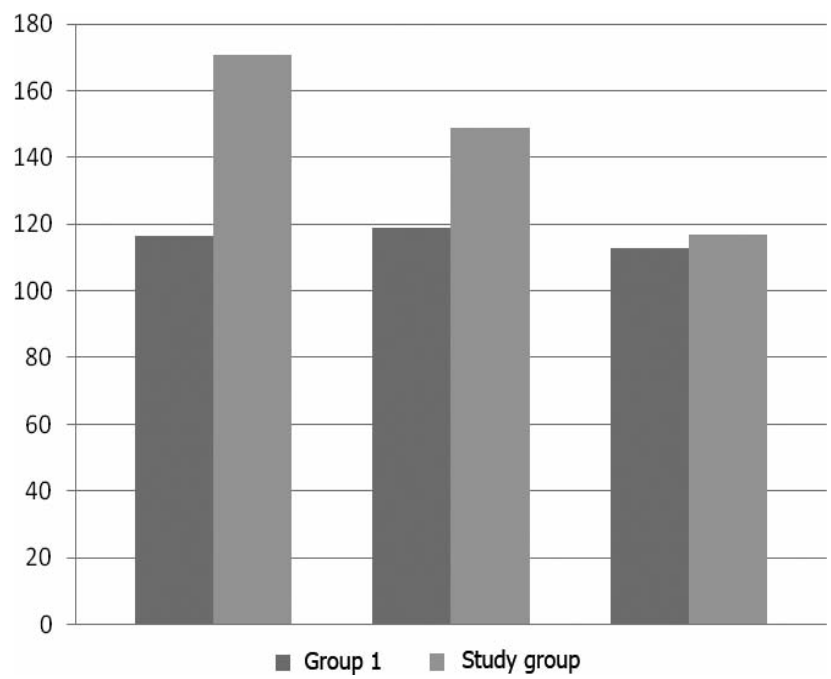

Table 1. Cytokine blood levels in healthy newborns on the third day of life.

\begin{tabular}{|l|l|l|l|l|l|l|l|l|}
\hline Cytokine & Patients & Mean & Median & Lowest & Highest & LQ & UQ & SD \\
\hline \multirow{3}{*}{ IL-4 $(\mathrm{pg} / \mathrm{ml})$} & Healthy & 20.11 & 18.73 & 9.62 & 32.07 & 16.71 & 22.90 & 5.886 \\
\cline { 2 - 10 } & Control & 24.73 & 22.89 & 13.05 & 42.25 & 17.16 & 29.25 & 9.056 \\
\cline { 2 - 9 } & Study & 20.59 & 18.08 & 14.35 & 32.52 & 17.1 & 22.10 & 5.581 \\
\hline & Healthy & 131.21 & 104.85 & 71.81 & 224.75 & 91.22 & 158.46 & 54.748 \\
\cline { 2 - 9 } IL-6 (pg/ml) & Control & 116.08 & 116.47 & 28.58 & 204.47 & 91.69 & 138.64 & 38.494 \\
\cline { 2 - 9 } & Study & 174.81 & 170.74 & 136.4 & 208.95 & 154.88 & 200.24 & 25.108 \\
\hline
\end{tabular}

LQ-lower quartile; UQ-upper quartile; SD-standard deviation 
Table 2. Comparative assessment of follow-up study of systemic inflammatory response indices in the group of recovered newborns and in the study group.

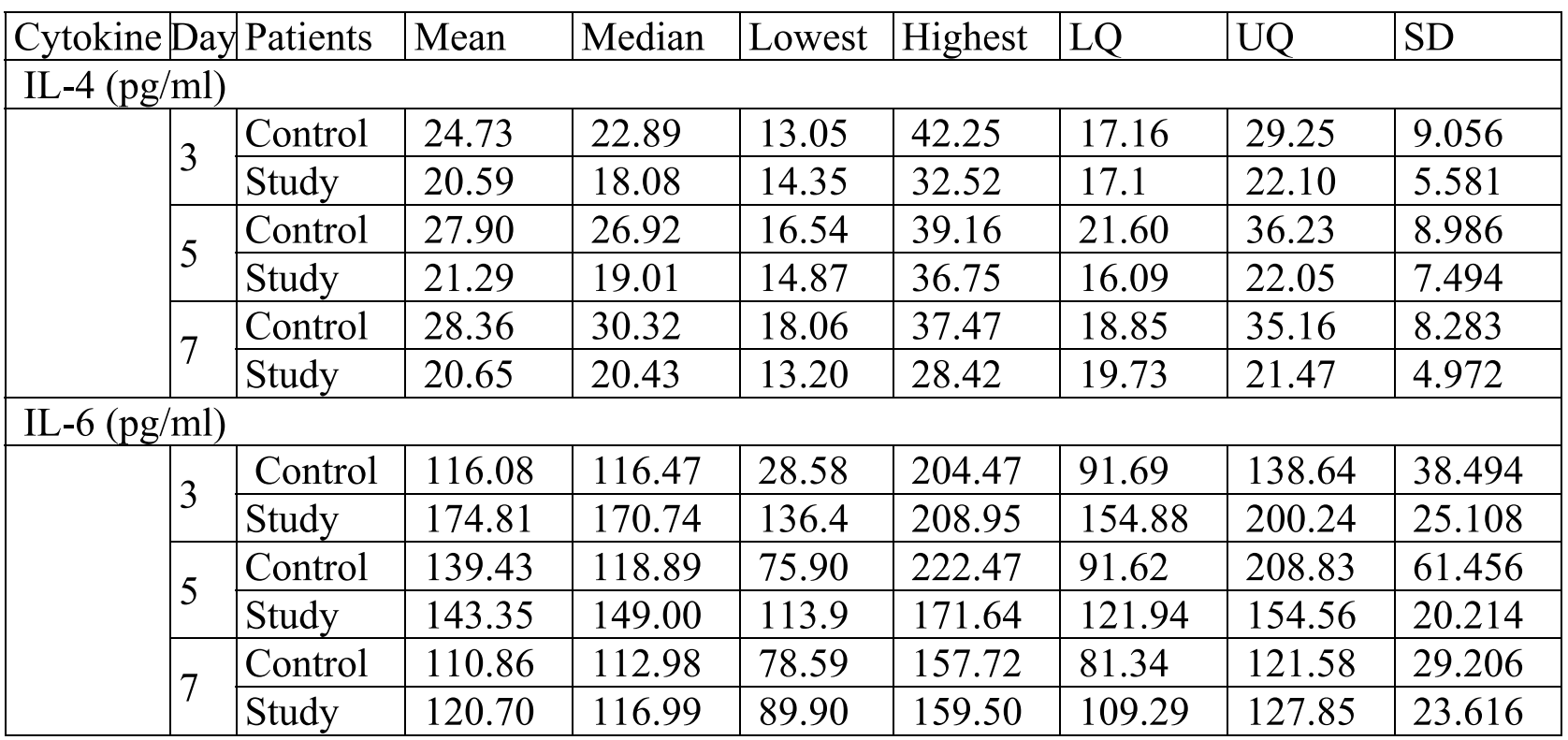

LQ-lower quartile; UQ-upper quartile; SD-standard deviation

whose therapy complex included the deproteinized hemodialysate from the newborn calf blood, is presented in table 2.

Presented data suggest that the level of antiinflammatory cytokine interleukin-4 in the study group was stable (18.08, 19.01 and $20.43 \mathrm{pg} / \mathrm{ml})$, it was significantly lower than in the group of newborns receiving standard therapy $(22.89,26.92$ and $30.32 \mathrm{pg} / \mathrm{ml})$ on $3^{\text {rd }}, 5^{\text {th }}$ and $7^{\text {th }}$ day, respectively. Besides, there was a tendency to its increase in this group throughout the study.

The level of pro-inflammatory cytokine interleukin-6 in the study group decreased throughout the study from $170.74 \mathrm{pg} / \mathrm{ml}$ on the $3^{\text {rd }}$ day to $149.00 \mathrm{pg} / \mathrm{ml}$ on the $5^{\text {th }}$ and by the $7^{\text {th }}$ day the levels of interleukin- 6 did not differ significantly in both groups $(116.99 \mathrm{pg} / \mathrm{ml}$ in the study group and $112.98 \mathrm{pg} / \mathrm{ml}$ in the control group).

\section{DISCUSSION}

Comparative analysis of anti-inflammatory interleukin-4 and pro-inflammatory cytokine interleukin-6 indices in the group of newborns receiving standard therapy and the group of newborns whose complex therapy included the deproteinized hemodialysate from the newborn calf blood allows us to state that the deproteinized hemodialysate from the newborn calf blood agent exerts an impact on synthesis of cytokines, since the level of anti-inflammatory cytokine in the control group increased throughout the study, inhibiting synthesis of proinflammatory cytokine.

The high level of pro-inflammatory cytokine on the third day was associated with a decrease in the oppressive effect of anti-inflammatory cytokines, whose synthesis was also reduced, while the effect of the deproteinized hemodialysate from the newborn calf blood also inhibited synthesis of pro-inflammatory cytokines, as evidenced by a dynamic decrease in interleukin-6 in the group of newborns whose therapy included the deproteinized hemodialysate from the newborn calf blood. By the seventh day the levels of pro-inflammatory cytokine interleukin-6 did not differ significantly.

Thus, the assessment of inflammatory indices of antiinflammatory cytokine interleukin-4 and proinflammatory cytokine interleukin-6 allows us to assume that the deproteinized hemodialysate from the newborn calf blood agent influences biochemical pattern of inflammation due to inhibition of synthesis of cytokines. The importance of cytokine had been demonstrated for pathogenesis of the range of diseases from neonatal sepsis to severe polytrauma $(8,9)$.

In conclusion, administration of the deproteinized hemodialysate from the newborn calf blood in the treatment of systemic inflammatory response in newborns with severe asphyxia at birth exerts influence on biochemical pattern of systemic inflammatory response by reducing inflammation and reducing synthesis of cytokines.

\section{REFERENCES}

1. Iarustovskiĭ MB, Abramian MV, Krotenko NP, et al. Experience of using endotoxin selective adsorption in patients with severe sepsis after open-heart surgery. Anesteziol Reanimatol 2014; (3): 39-46. (in Russian). 
2. Kozlov IA, Poptsov VN, Alferov AV. Methylene blue as an inhibitor of endogenous nitric oxide overproduction in the correction of postperfusion vascular insufficiency. Annals of Critical Care 2002; (2): 7-12. (in Russian).

3. Khubutiia MSh, Abakumov MM, Aleksandrova IV, et al. Selective adsorption of endotoxin in the complex treatment of patients with severe sepsis. Anesteziol Reanimatol 2010; (5): 65-9. (in Russian).

4. Chukanova EI, A N Bogolepova AN. Perspectives of the use of solcoseryl in the therapy of ischemic encephalopathy. Zh Nevrol Psikhiatr Im S S Korsakova 2007; Suppl 21: 57-64. (in Russian).

5. Opal SM. The host response to endotoxin, antilipopolysaccharide strategies, and the management of severe sepsis. Int J Med Microbiol 2007; 297: 365-77.

6. Khoroshilov SY, Karpun NA, Polovnikov SG, Nikulin AV, Kuzovlev AN. Selective hemosorption of endotoxin in the treatment of abdominal sepsis. General Reanimatology 2009; 5: 83-7. (in Russian).
7. Dziak LA, Golik VA. Experience gained with Solcoseryl as treatment of patients with cerebral hemorrhage. Lik Sprava 2001; (4): 162-8. (in Russian).

8. Ashidkova NV, Volodin NN, Degtyareva MV, et al. The effectiveness of the drug recombinant human interleukin-2 in the treatment of neonatal sepsis and severe neonatal infections. Pediatrics 2009; 87: 80-6.

9. Malysh IR, Treshchinskiı̌ AI, Shlapak IP, Zgrzheblovskaia LV. Effect of analgesic sedation on the cytokine profile in victims with severe polytrauma. Anesteziol Reanimatol 2007; (4): 30-3. (in Russian).

10. Novelli G, Ferretti G, Poli L, et al. Clinical results of treatment of postsurgical endotoxin-mediated sepsis with polymyxin-B direct hemoperfusion. Transplant Proc 2010; 42: 1021-4.

11. Kligunenko EN, Kozina OS. Influence of thromboprophylaxis with bemiparin on markers of inflammation. Pain Anesthesia and Intensive Care 2013; (3): 9-12. (in Russian). 